\title{
Discurso do \\ Doutor Fidelis Policarpo Cabral de Almada
}

Senhor Reitor da Universidade de São Paulo;

Senhor Presidente da Congregação da Faculdade de Direito da USP;

Senhor Diretor da Faculdade de Direito da USP;

Senhores Professores;

llustres convidados,

Desejaria começar por exprimir o meu vivo agradecimento à direção da Faculdade de Direito desta Universidade, às ilustres personalidades que me precederam no uso da palavra para, neste ato tão solene quanto gratificante, exaltar, através da minha pessoa, a amizade e a fraternidade tradicionais entre o Brasil e a Africa, entre brasileiros e africanos.

O meu agradecimento é ainda extensivo a todos os convidados que, com a sua ilustre presença, contribuíram para conceder a esta sessão uma maior dimensão e alcance.

A distinção que hoje me é concedida constitui uma grande honra e motivo de imensa satisfação: é com a mais sincera emoção que me revejo nesta velha e prestigiosa "Casa" que em 1962 me concedeu o grande científico e onde estabeleci laços humanos cuja qualidade têm resistido à erosão do tempo e da distância!

Neste reencontro exaltante, é com grande satisfação que revivo algumas das mais belas imagens registradas na minha vida:

- As Arcadas de "São Francisco" e os seus doutos Professores que me transmitiram conhecimentos jurídicos através de métodos até então desconhecidos, métodos humanos e prenhes de calor, dos quais o Senhor Professor Doutor VICENTE MAROTTA RANGEL, aqui presente, é lídimo representante;

- O Centro de Estudos Africanos e alguns inestimáveis colegas e amigos co-fundadores, nomeadamente o Senhor Professor Doutor FERNANDO ALBUQUERQUE MOURÃO; 
- Os ensinamentos do Senhor Professor Doutor ALFREDO BUZAID e os primeiros passos do jovem advogado que era em 1962, sob a orientação desse conceituado mestre e amigo;

Mas, desde então, nada menos de vinte anos são volvidos. Vinte anos em que os conhecimentos e a experiência adquiridos neste belo e grande país foram muitas vezes fator determinante da minha atuação e de alguns sucessos por mim registrados.

Efetivamente, tendo regressado à Āfrica em 1964 para integrar as fileiras dos combatentes da liberdade da minha pátria, no seio do PAIGC (Partido Africano da Independência da Guiné e Cabo Verde), o saber e a experiência aqui adquiridos revelaram-se de extrema importância no cumprimento das tarefas e na solução dos problemas administrativos, judiciários e políticos concernentes à organização do Estado, emergente da libertação firme e progressiva de parcelas cada vez mais importantes do território nacional.

Hoje, oito anos após a independência do meu país, tais conhecimentos, testados durante duas décadas de experiência política e oito de governação efetiva, continuaram a consubstanciar parte essencial da minha cultura e da minha própria personalidade.

Poucos anos após a independência nacional, tendo tomado consciência da tremenda falta de quadros com que o país se debatia, coloquei o meu maior empenho na sensibilização do nosso Governo com vista à criação de condições que permitissem a realização, em território nacional, de estudos jurídicos, tendentes à formação de juristas que pudessem assegurar uma reciclagem dos Servidores do Estado e garantir uma justiça material no quadro de uma sociedade democrática de paz e progresso, que pretendemos instalar no nosso pais.

Esse empenho viria a ser coroado de êxito em 1979, através da criação em Bissau, por Decreto Governamental, da Escola de Direito, instituição destinada ao ensino das Ciências Jurídicas e planificada para conceder, neste domínio, o grau de bacharel, num curso de três anos.

Grato me é referir, ilustres senhores, que, no ato solene de inauguração da nossa Escola de Direito, em Bissau, a USP fez-se representar condignamente pelos Senhores Professores Doutores FRANCO DA FONSECA e FERNANDO ALBUQUERQUE MOURÃO, na seqüência de esforços por mim desenvolvidos - enquanto brasileiro e paulista de coração - no sentido de estabelecer a mais estreita cooperação entre nossa prestigiosa Universidade e a jovem instituição guineense acabada de nascer.

Porém devemos reconhecer que, decorridos já três anos, a cooperação entre as duas instituições irmãs vem-se saldando apenas em visitas esporádicas de eminentes Catedráticos da Faculdade de Direito 
da USP, que até nós têm, efetivamente, levado a sua solidariedade e a luz do seu saber, proferindo conferências sobre temas pontuais das Ciências Jurídicas e Sociais.

Este nível de cooperação, em nossa opinião, ainda, não reflete as expectativas carinhosamente acalentadas pela Guiné-Bissau.

Com efeito, embora cientes das limitações e dificuldades que o processo seguramente ainda levanta a esta Universidade paulista, a cooperação pretendida pela parte guineense, porque a expressão da vontade política nacional e estatal, pressupõe e sugere a necessidade de configuração de um quadro institucional eficaz e capaz de a tornar, cada vez mais estreita, multiforme, mutuamente vantajosa e exemplar.

$E$ neste contexto e com tais objetivos que realizamos a presente missão à República Federativa do Brasil e à Universidade de S. Paulo: trazemos conosco, com efeito, idéias e projetos suscetíveis de dinamizar a nossa cooperação e elevá-la ao nível por nós desejado.

Para isso contamos com a clarividente boa vontade dos irmãos que aqui outrora deixamos, assim como daqueles que viemos conhecer !

SENHOR REITOR !

SENHOR PRESIDENTE DA CONGREGAÇÃO DA FACULDADE DE DIREITO DA USP!

SENHOR DIRETOR DA FACULDADE !

\section{SENHORES PROFESSORES !}

\section{ILUSTRES CONVIDADOS !}

Para terminar permitam-me aproveitar este ensejo para renovar os nossos agradecimentos e manifestar a nossa firme determinação de envidar todos os esforços para que viva a amizade e a fraternidade entre o grande povo brasileiro e o povo guineense.

Muito obrigado. 